\title{
Peran Spiritualitas Keagamaan Bagi Akuntan dalam Lingkungan Organisasi
}

\author{
Agung Budi Sulistiyo \\ Fakultas Ekonomi Universitas Jember \\ Jl. Jawa No. 17 Tegalboto Jember 68121 \\ Email: agungbudisulistiyo@gmail.com
}

\begin{abstract}
This paper tries to connect the values of religion, spirituality and work place of an accountant. One of the reasons why there is unethical attitude of an accountant is the disappearance of spirituality values. The disappearance of these values can be caused by work stress on either body or soul faced by an accountant. Spirituality Diversity Model has been proposed by Krishnakumar and Neck (2002) to replace spirituality values of religion so that spirituality concept become higher and holier than religion. Religion must be placed on spirituality values. Religion is the guidance for human to behave and act in the world. This model is named as Religion Values Model (RVM). The result of empirical research by Sulistiyo (2004) strengthens $R V M$ that internal auditor spiritual values would improve integrity of profession and its organisation including capability to adapt and anticipate the transformation of organisation or company. In fast changing environment, accountant must have self identity. The modernisation and postmodernisation mind set must be responded critically and wisely. Not all that come from the West always gives positive effect. This self identity would strengthen existence of an accountant as better professionals. This self identity certainly could be found in religion values.
\end{abstract}

Keywords: Accountant, Spirituality, Religion, RVM.

Sukoharsono (2008) said "accounting is not just a simple of numbers and tables, it is also about spirituality that is a meta-physical matter"

\section{Pendahuluan}

Melalui sejarah yang panjang, akuntansi mengalami evolusi dari waktu ke waktu. Ada pandangan yang mengatakan bahwa akuntansi pada abad modern sebenarnya dikembangkan dalam sebuah lingkungan yang sarat dengan konteks sosial, budaya, hukum, norma, agama dan variabel lainnya sehingga dikatakan akuntansi dipengaruhi oleh lingkungan dimana ia dibentuk (socially constructed) (Morgan, 1988; Francis, 1990; dan Hines, 1992). Terlihat adanya doktrin kapitalisme pada praktek akuntansi modern saat ini dimana kekuatan kapitalisme yang besar baik nyata ataupun tersamar telah mengkooptasi dan mengeksploitasi kehidupan manusia dan alam semesta secara sistematis sehingga akuntansi tidak lebih sebagai instrumen mati yang digunakan untuk memperkokoh kekuatan kapitalisme (Triyuwono, 2006).

Pada sisi yang lain konsekuensi dari penerapan akuntansi modern tersebut menunjukkan dampak yang kurang memuaskan. Fakta menunjukkan banyaknya skandal akuntansi dan manipulasi laporan keuangan yang melanda perusahaan serta rendahnya kepedulian mereka akan tanggung jawab sosial dan lingkungan menyiratkan bahwa terjadi perubahan yang sangat besar pada para pelaku akun-

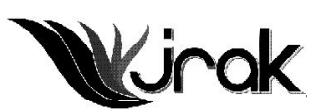

Jurnal Reviu Akuntansi dan Keuangan ISSN: 2088-0685 Vol.1 No. 2, Oktober 2011 Pp 127-139 


\section{Peran Spiritualitas Keagamaan...}

tansi. Kondisi ini menggambarkan bahwa akuntansi telah gagal untuk menggambarkan realitas bisnis secara utuh. Triyuwono (2006) menyatakan bahwa akuntansi modern tidak mampu merefleksikan realitas non ekonomi yang diciptakan perusahaan. Ia hanya mampu mengakui dan merefleksikan peristiwa ekonomi saja. Triyuwono (2006) juga secara sistematis menjelaskan beberapa kelemahan yang muncul berkaitan dengan praktik akuntansi konvensional (modern) yakni:

Akuntansi modern mengabaikan dua aspek penting yaitu lingkungan dan sosial sehingga gagal menggambarkan realitas bisnis yang semakin kompleks;

Sifat egoisme sangat melekat pada akuntansi modern sehingga terefleksi ke dalam bentuk private costs/benefits dan berorientasi melaporkan profit untuk kepentingan pemilik modal/pemegang saham. Oleh karena itu informasi akuntansi menjadi egois dan mengabaikan pihak lain.

Akuntansi modern lebih bersifat materialistik sehingga memarjinalkan nilainilai spiritualitas padahal manusia sebagai pelaku akuntansi memiliki dua hal tersebut yakni material dan spiritual. Jika manusia diarahkan untuk menjalankan praktik akuntansi yang beorientasi pada materi (profit) maka perilaku yang muncul berkaitan dengan upaya pencapaian tujuan tersebut berpotensi melanggar aturan dan kehilangan nilai-nilai etika, agama dan moralitas.

Oleh karena itu bisa kita pahami bahwa ketika akuntansi modern mampu menghadirkan realitas sosial dengan semangat kapitalismenya maka yang terjadi adalah praktek-praktek akuntansi yang bebas dari nilai-nilai lokalitas masyarakat (value free) sehingga realitas sosial tersebut menjadi parsial (tidak utuh). Kondisi ini juga menyiratkan penerapan hukum universal dalam ekonomi mainstream (termasuk akuntansi) memiliki potensi kuat untuk memberangus nilai-nilai local (local wisdom) yang berlaku dalam masyarakat (Muhammad, 2008). Di sisi yang lain, adanya sifat yang parsial ini melahirkan budaya masyarakat yang mengabaikan nilai-nilai etika, moralitas dan keberagaman sosial maupun spiritualitas keagamaan. Hal ini ditegaskan oleh Triyuwono (2006) bahwa akuntansi modern hanya concern dengan dunia materi dan sebaliknya mengabaikan dan mengeliminasikan dunia non-materi (spiritual). Dengan demikian patut diyakini bahwa mengembangkan akuntansi ditinjau dari perspektif sosio historisnya perlu memasukkan aspek value untuk menciptakan wajah akuntansi yang sarat dengan nilai (value laden). Akuntansi yang bernilai diharapkan mampu menjadikan praktek akuntansi yang mendorong perilaku manusia lebih beragama, bernilai spiritualitas dan beretika dalam kehidupan sosial dan lingkungannya.

Profesi akuntan dengan variasi pekerjaannya (termasuk akuntan intern, staf akuntansi dan bidang lain sepanjang masih berhubungan dengan kegiatan akuntansi) mengalami tekanan baik fisik maupun mental yang tidak ringan dalam dunia kerjanya. Stereotip pekerjaan yang monoton, berulang-ulang dan cenderung membosankan serta atribut lainnya mendorong rasa frustasi dan kegelisahan dalam bekerja (Krishnakumar dan Neck, 2002). Hal ini juga dapat berdampak pada perilaku negatif seorang akuntan yang mempengaruhi nama baik profesi di mata masyarakat atau publik. Salah satu asumsi yang dijadikan sebagai penyebab dari perilaku negatif seorang akuntan adalah hilangnya atau berkurangnya nilai-nilai spiritualitas keagamaan dalam dirinya. Hilangnya nilai-nilai spiritualitas keagamaan ini mengakibatkan seorang akuntan tidak dapat lagi membedakan mana perbuatan yang baik dan buruk, serta beretika atau melanggar etika (Sulistiyo, 2004). Oleh karena itu menjadi penting membahas konsep spiritualitas keagamaan dalam dunia akuntan. Paper berikut pada bagian awal tidak membahas secara spesifik dunia kerja akuntan namun pembahasannya bersifat umum. Penulis berpikir kondisi dunia kerja secara umum berlaku juga secara khusus di dunia kerja akuntan.

Paper ini diawali dengan satu pertanyaan dasar "mengapa banyak ketertarikan yang muncul berkaitan dengan spiritualitas dalam dunia kerja ? Karena orang berhasrat untuk meningkatkan pengalaman spiritualnya yang bukan hanya 
bersifat pribadi (personal) tetapi juga dalam dunia kerja, sebuah dunia dimana mereka banyak menghabiskan waktunya. (Neck \& Milliman, 1994; Ray 1992; Maynard 1992). Beberapa temuan empiris menunjukkan adanya keterkaitan antara spiritualitas dengan dunia kerja diantaranya ada hubungan antara spiritualitas dunia kerja dengan meningkatnya kreatifitas individu (Freshman 1999), meningkatkan kejujuran dan kepercayaan dalam organisasi (Wagner-Marsh \& Conely 1999), meningkatkan rasa kepuasan pribadi karyawan (Burrack 1999) dan meningkatnya komitmen terhadap tujuan organisasi (Delbecq 1999; Leigh 1997).

Paper ini diinspirasi oleh empat literatur yang mendasari pemahaman tentang spiritualitas dalam dunia kerja. Paper pertama adalah tulisan Krishnakumar dan Neck (2002), Sukoharsono (2008), dan hasil riset empiris Sulistiyo (2004) serta salah satu bab dari bukunya Roslender yakni Sosiological perspectives on modern accountancy (1992) tentang accountant's work experience. Ada tiga pertanyaan penting sebagai turunan dari pertanyaan dasar di awal yaitu pertama, "what" berkaitan dengan apa hakikat sebenarnya dari spiritualitas dalam dunia kerja, kedua, "why" yaitu manfaat yang diperoleh organisasi jika manajer mendorong implementasi konsep spiritualitas diantara anggota-anggota organisasi dan ketiga, "how" yakni cara mengimplementasikan spiritualitas tersebut dalam perusahaan. Ketiga pertanyaan tersebut akan dijawab secara eksplisit maupun implisit dalam paparan selanjutnya.

"There are different views on the meaning of spirituality, given that this concept is very personally driven"

\section{Definisi Spiritualitas}

Ada tiga sudut pandang (perspektif) dalam melihat konsep spiritualitas ini yakni the intrinsic-origin, pandangan agama (religious) dan existentialist view.

\section{Sudut pandang the intrinsic-origin}

Dalam pandangan ini menyatakan bahwa spiritualitas adalah sebuah konsep atau prinsip yang berasal dari dalam diri seseorang (individu). Guillory's (2000) lebih jauh mengatakan bahwa spiritualitas merupakan bentuk kesadaran dalam diri kita yang melewati batas-batas nilai-nilai (values) dan keyakinan (beliefs) yang kita miliki termasuk peraturan bahkan agama. Sejalan dengan pendapat tersebut, Graber (2001) menyatakan pandangannya sebagai berikut:

\section{"spirituality avoids the formal and ceremonial connotations of religion; it is non denominational, non-hierarchical, and non-ecclesiastical. Spirituality implies an inner search for meaning or fulfillment that may be undertaken by anyone regardless of religion}

Penulis mencoba menyimpulkan berdasarkan beberapa definisi dari sudut pandang the intrinsic-origin tersebut secara eksplisit menegaskan bahwa spiritualitas lebih luas dari konsep agama, terlepas dari agama apapun itu juga. Spiritualitas berdiri di atas semua agama yang ada di dunia ini bahkan mungkin agak sedikit bombastis, penulis menyebut spiritualitas adalah jauh lebih suci dibandingkan agama yang kita yakini. Spiritualitas bersifat sangat personal, bebas dan tidak terikat dengan aturan-aturan dogmatis. Oleh karenanya spiritualitas setiap orang akan sangat mungkin berbeda karena tidak ada aturan ataupun nilai-nilai yang mengikatnya.

\section{Sudut pandang agama (religions)}

Mengutip pernyataan Bruce (1996) yang menyatakan bahwa definisi spiritualitas sangat dipengaruhi oleh keyakinan beragama seseorang sehingga agama yang berbeda sedikit banyak akan memiliki perbedaan dalam cara memandang konsep spiritualitas. Berikut kutipan Bruce (1996): "Religion consists of beliefs, actions, and institutions which assume the existence of supernatural entities with 


\section{Peran Spiritualitas Keagamaan...}

130 powers of action, or impersonal powers or processes possessed of moral purpose “. Cara pandang spiritualitas dalam dunia kerja dari masing-masing agama dapat dijelaskan sebagai berikut (dalam Krishnakumar dan Neck, 2002; Sulistiyo, 2004):

\section{Agama Kristen}

Bahwa partisipasi kita bekerja dalam dunia ini dalam kerangka kreatifitas Tuhan merupakan sebuah keberkatan karena pada dasarnya bekerja merupakan panggilan Tuhan.

\section{Agama Hindu}

Mereka percaya bahwa spiritualitas adalah melakukan pekerjaan sebagai bentuk pengabdian. Menjadi satu hal yang harus digarisbawahi bahwa "usaha" untuk mencapai tujuan merupakan hal yang paling penting sedangkan "hasilnya" sepenuhnya diserahkan kepada Tuhan.

\section{Agama Budha}

Melihat bahwa bekerja keras dan pengabdian adalah alat yang digunakan untuk mengubah hidup seseorang dan institusi secara keseluruhan.

\section{Agama Islam}

Menggunakan istilah etika kerja Islami (Islamic Work Ethic) dalam Yousef (2000) yang menekankan komitmen dan kerjasama antar karyawan untuk mencapai keberhasilan organisasi. Di sisi yang lain Yousef (2000) juga menegaskan pentingnya nilai-nilai (values) dan keadilan (justice) dalam sebuah organisasi.

\section{Agama Protestan}

Mengutip pandangan Martin Luther dalam Naylor et al(1966) bahwa Tuhan secara terus-menerus akan menciptakan segala sesuatu sedangkan manusia diminta untuk ikut berpartisipasi di dalamnya.

\section{Sudut pandang existentialist}

Dalam pandangan Existentialist, memaknai spiritualitas dalam dunia kerja sebagai sebuah konsep pencarian hakikat (meaning) dari aktifitas kerja yang kita lakukan. (Naylor et al 1996; Neck \& Milliman 1994; Kahnweiler \& Otte 1997). Oleh karenanya beberapa pertanyaan yang sering muncul (dikutip dari Krishnakumar \& Neck (2002) seperti why am I doing this work? what is the meaning of the work I am doing? where does this lead me to? is there a reason for my existence and the organization's?

Seringkali pertanyaan-pertanyaan demikian tepat jika dimunculkan pada saat seseorang bekerja dalam intensitas yang berulang-ulang dan cenderung membosankan. Hal ini bisa mendorong munculnya penyakit eksistensialis (existentialist sickness). (Naylor et al. 1966). Jika penyakit ini dibiarkan maka akan muncul rasa keterasingan pada dirinya yang selanjutnya akan mengurangi tingkat produktifitas kerjanya bahkan tak jarang muncul frustasi yang berlebihan.

Dalam profesi akuntan, pekerjaan akuntansi cenderung berulang-ulang dan membosankan. Mencatat transaksi, membuat jurnal, merekap buku besar, dan menyusun laporan keuangan membutuhkan ketelitian dan kesabaran bahkan kehati-hatian yang tinggi. Jika ada kesalahan sedikit saja maka dampaknya bisa besar bagi keuangan organisasi atau perusahaan. Begitu juga profesi akuntan publik dalam melakukan pekerjaannya juga mengikuti sistem dan prosedur yang baku sehingga kebosanan yang berujung pada mandegnya kreatifitas dalam kerja sangat mungkin terjadi.

"The lack of a meaning in the daily work, can lead to existential sickness and the lack of meaning of purpose of work can lead to alienation from oneself" 
Banyak penelitian yang menyarankan untuk mengimplementasikan nilainilai spiritualitas ke dalam profesi atau dunia kerja yang digelutinya. Ada beberapa manfaat yang dapat dipetik meliputi "kreatifitas", "kejujuran dan kepercayaan", "pemenuhan pribadi (personal fulfillment), dan "komitmen" yang kesemuanya akan mendorong peningkatan kinerja organisasi.

\section{Intuisi dan kreatifitas}

Dengan spiritualitas akan mendorong lahirnya sebuah kesadaran, melalui kesadaran ini maka akan muncullah intuisi, selanjutnya intuisi ini akan melahirkan sebuah kreatifitas (Freshman 1999). Demikian pula dengan semakin kaya nilainilai spiritual yang dimiliki karyawan akan mendorong munculnya kepuasan dan kebahagiaan sehingga karyawan akan jauh lebih kreatif (Turner 1999). Selanjutnya Turner (1999) juga menegaskan bahwa kreatifitas seorang karyawan akan meningkatkan kinerja keuangan dan keberhasilan perusahaan secara keseluruhan.

\section{Kejujuran dan kepercayaan (honesty and trust)}

Banyak organisasi menempatkan nilai-nilai kejujuran sebagai fokus utama yang harus dimiliki (Burack 1999). Dengan kejujuran maka setiap pikiran dan tindakan akan seiring sejalan dengan tujuan dan aturan organisasi. Banyak kasuskasus besar yang terungkap dalam praktek akuntansi seperti kecurangan (financial fraud), manipulasi dan rekayasa laporan keuangan serta tindakan pelanggaran etis lainnya ditengarai merupakan ketidakjujuran akuntan dalam menjalankan profesinya.

Dalam kondisi ekonomi yang sedang depresi seringkali perusahaan akan mengalami masalah keberlangsungan usaha (going concern) sehingga sangat dibutuhkan adanya kepercayaan (trust) antara pihak manajemen dan karyawan untuk dapat melalui masalah ini dengan sebaik-baiknya. Menurut Kriger dan Hanson (1999) dengan kepercayaan akan mendorong kinerja organisasi menjadi lebih baik melalui akselerasi pengambilan keputusan, komunikasi antar manajer yang lebih optimal dan fokus pada pencapaian kepuasan pelanggan serta daya inovasi yang semakin meningkat.

\section{Aktualisasi diri (personal fulfillment)}

Jika dihubungkan dengan teori piramida kebutuhan Maslow maka kebutuhan akan aktualisasi diri menempati tingkatan yang paling tinggi. Seseorang yang memiliki nilai spiritualitas yang tinggi akan merasakan sesuatu yang "utuh" dalam dirinya dalam bekerja sehingga berefek pada meningkatnya nilai-nilai moral dan kebutuhan akan aktualisasi diri (Krishnakumar dan Neck, 2002). Konsekuensinya tentu akan berdampak positif pada kinerja atau keberhasilan organisasi.

\section{Komitmen profesi dan komitmen organisasi}

Pada dasarnya nilai-nilai spiritualitas akan meningkatkan komitmen karyawan melalui budaya kepercayaan yang terbentuk di organisasi (Burack 1999). Komitmen profesi diartikan sebagai intensitas identifikasi dan keterlibatan kerja individu dengan profesi tertentu. Identifikasi ini membutuhkan beberapa tingkat kesepakatan dengan tujuan dan nilai profesi termasuk nilai moral dan etika (Mowday et al. 1979). Komitmen juga didefinisikan dalam literatur akuntansi sebagai berikut (Aranya \& Ferris 1984):

1. Suatu keyakinan dan penerimaan tujuan dan nilai suatu profesi.

2. Kemauan untuk memainkan upaya tertentu atas nama profesi.

3. Gairah untuk mempertahankan keanggotaan pada suatu profesi. 


\section{Peran Spiritualitas Keagamaan...}

Komitmen pada profesi dikembangkan selama mengikuti proses sosialisasi yang menyertai masuknya profesi, yang bisa terjadi selama mengikuti kuliah di perguruan tinggi dan pada permulaan karir. Selama periode itu, proses afiliasi dengan nilai profesional dikembangkan dengan kuat (Aranya et al. 1994) dalam Nasron (2002). Hal yang sama juga dikemukakan oleh Larson (1997) dan Jeffrey et. al. (1996) dalam Astri (2003) bahwa komitmen profesi berkembang selama proses sosialisasi ke dalam profesi yang dipilih bilamana penekanan-penekanan diberikan pada nilai-nilai profesi.

Robins (2001) mengatakan bahwa komitmen organisasi merupakan suatu keadaan atau derajat sejauhmana seorang karyawan memihak pada suatu organisasi tertentu dan tujuan-tujuannya serta berniat memelihara keanggotaan dalam organisasi tersebut. Konstruksi dari komitmen organisasi memusatkan perhatian pada kesetiaan karyawan terhadap organisasi. Hal ini menunjukkan kondisi psikologis atau orientasi karyawan terhadap organisasi yang bersedia mengeluarkan kemampuan terbaiknya demi kepentingan perusahaan.

Meyer \& Allen (1984) mengungkapkan bahwa penelitian yang dilakukan oleh Becker (1960) memberikan gambaran komitmen organisasi yang lebih kompleks karena membedakan atas fact of commitment dan bases of commitment. Fact of commitment berkaitan pada sesuatu (grup atau individu) yang menunjukkan komitmen seseorang berdasarkan pada sasaran yang diinginkan sedangkan bases of commitment merujuk pada dasar atau motif yang menyebabkan seseorang mempunyai komitmen terhadap sesuatu. Selanjutnya Meyer \& Allen (1984) menyebutkan pendapat Becker (1960) bahwa bases of commitment yang dominan adalah side bets orientation yang mencerminkan akumulasi investasi seseorang yang hilang jika meninggalkan organisasi dan individual-organizational goal congruence orientation yang mencerminkan penerimaan dan pengidentifikasian seseorang terhadap tujuan-tujuan organisasional.

Meyer et al. (1993) mengemukakan tiga komponen tentang komitmen organisasi yaitu:

1) Affective Commitment terjadi apabila karyawan ingin menjadi bagian dari organisasi karena adanya ikatan emosional (emotional attachment). Jadi karena ia memang menginginkan (want to).

2) Continuance Commitment muncul apabila karyawan tetap bertahan pada suatu organisasi karena membutuhkan gaji dan keuntungan-keuntungan lain atau memang ia tidak menemukan pekerjaan lain. Dengan kata lain ia membutuhkan (need to).

3) Normative Commitment timbul dari nilai-nilai diri karyawan. Karyawan bertahan menjadi anggota organisasi karena ada kesadaran bahwa berkomitmen terhadap organisasi merupakan hal yang memang seharusnya dilakukan. Jadi karena ia merasa berkewajiban (ought to).

Secara tegas Meyer et al. (1993) mengatakan bahwa seseorang dapat mempunyai pemahaman yang lebih bagus mengenai hubungan karyawan dengan organisasi tatkala ketiga bentuk komitmen tersebut dipertimbangkan secara bersama-sama.

\section{Kinerja organisasi (organizational performance)}

Penemuan empiris menunjukkan bahwa organisasi yang kaya dengan nilainilai spiritualitas akan mendorong kinerja organisasi yang lebih baik (Neck and Milliman 1994). Fakta lain juga mengungkapkan organisasi yang mendorong spiritualitas sebagai nilai-nilai yang digunakan akan meningkatkan profit dan kesuksesan organisasi (Turner 1999). Menurut Mitroff dan Denton (1999) tidak ada organisasi yang dapat bertahan lama tanpa nilai-nilai jiwa (soul) dan spiritualitas.

Berdasarkan konsep spiritualitas yang dibangun dalam organisasi akan melahirkan nilai-nilai (values) yang sudah dijelaskan sebelumnya meliputi intuisi dan kreatifitas; kejujuran dan kepercayaan; aktualisasi diri, komitmen profesi dan 
komitmen organisasi; serta kinerja organisasi merupakan pondasi yang bagus untuk membangun lingkungan kerja yang bergairah dan dinamis.

"No organization can survive for long without spirituality and soul"

\section{Implementasi NIlai- Nilai Spiritualitas Dalam Dunia Kerja}

Ada dua perspektif yang dapat digunakan untuk melihat implementasi nilainilai spiritualitas dalam sebuah organisasi yaitu pertama, perspektif yang berpusat pada organisasi (organization-centered perspective) dan kedua, perspektif yang berpusat pada individu (individual-centered perspective).

\section{Perspektif yang berpusat pada organisasi}

Pendekatan ini memandang bahwa nilai-nilai spiritualitas seharusnya diimplemantasikan ke dalam organisasi secara keseluruhan. Hal ini sejalan dengan hasil penelitian Mitroff dan Denton (1999) yang menunjukkan bahwa ada kemungkinan terjadi konflik kepentingan dan keinginan antara karyawan dalam interaksi kerjanya sehingga dapat mengganggu kinerja perusahaan. Konflik kepentingan dan keinginan tersebut dapat disebabkan oleh perbedaan nilai-nilai spiritualitas yang diyakininya. Jika kondisi ini dibiarkan tentunya akan menimbulkan perpecahan dalam organisasi sehingga tujuan-tujuan yang sudah disusun tidak dapat tercapai. Pandangan ini menawarkan konsep bahwa nilai-nilai spiritualitas mustinya dikendalikan oleh perusahaan bukan diserahkan kepada individu-individu. Oleh karena itu Mitroff dan Denton (1999) mengklasifikasikan organisasi berdasarkan pada prinsip-prinsip spiritualitasnya menjadi lima yakni "religion based", evolutionary, recovering, socially responsible, dan values based.

\section{Perspektif yang berpusat pada individu}

Pada perspektif ini maka konsep spiritualitas dilihat dari sudut pandang individu. Bahwa organisasi semestinya menghargai dan mengakomodasi berbagai nilai spiritualitas masing-masing individunya (karyawan). Seorang pemimpin dalam suatu organisasi seyogyanya berusaha untuk menerima dan memahami variasi spiritualitas yang ada sebagai konsekuensi dari keberagaman individu dalam organisasi. Hal ini dipertegas oleh Leigh (2007) yang menyatakan bahwa spiritualitas adalah bentuk pengakuan ketika seseorang datang untuk bekerja lebih daripada sekedar tubuh dan pikirannya akan tetapi juga mereka membawa talenta dan spirit yang unik. Berikut model yang dikembangkan oleh Krishnakumar \& Neck (2002) mengenai implementasi nilai-nilai kebebasan spiritualitas berbasis individu.

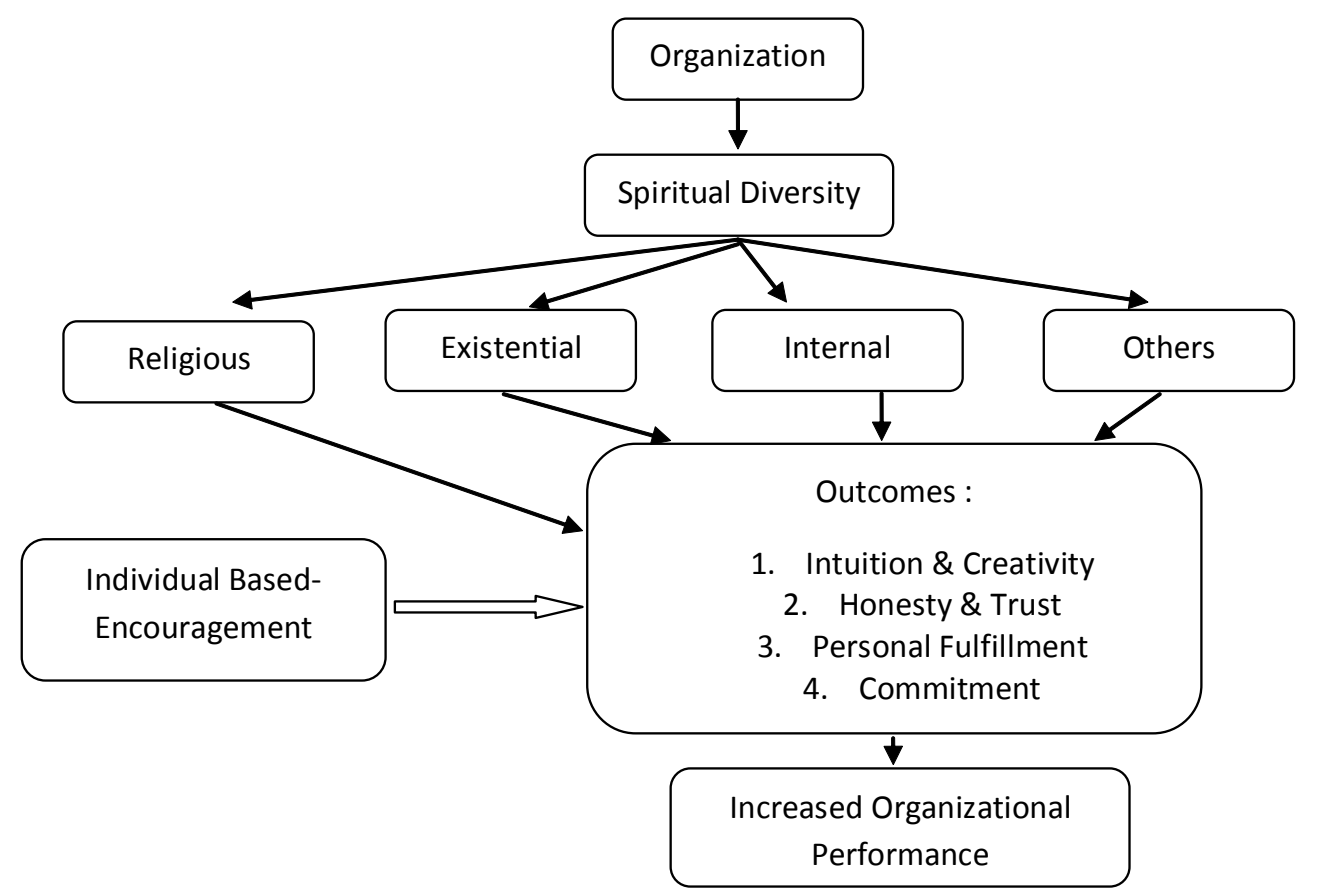

Gambar 1

Model Spiritual

Diversity 


\section{Peran Spiritualitas Keagamaan...}

Krishnakumar \& Neck (2002) ingin menunjukkan bahwa organisasi tidak punya hak untuk mengekang kebebasan spiritual individu-individu di dalamnya. Pengekangan kebebasan akan berakibat negatif terhadap kinerja organisasi karena munculnya disharmonisasi hubungan antara individu dengan organisasi. Oleh karena itu, tugas organisasi adalah memfasilitasi dan mendorong masing-masing individu untuk mengembangkan nilai-nilai spiritualitasnya sehingga kinerjanya sebagai individu akan meningkat dan selanjutnya berpengaruh terhadap kesuksesan kinerja organisasi.

\section{Sintesa pemikiran penulis}

Sebuah organisasi berjalan karena ada interaksi antar individu di dalamnya. Semakin baik interaksi antar individu akan mendorong kerjasama, tolong menolong, toleransi dan kekompakan dalam bekerja sehingga berdampak pada kesehatan organisasi. Jika penerapan nilai-nilai spiritualitas diserahkan sepenuhnya kepada organisasi dan mengabaikan keragaman spiritualitas individu maka terjadilah kondisi yang otoriter. Individu dipaksa untuk menerapkan nilai-nilai spiritualitas yang dirinya tidak meyakininya. Rasa frustasi, merasa dikekang atau tidak nyaman dalam bekerja merupakan beberapa disfungsi perilaku (behavioral dysfunction) yang akan terlihat dari setiap individu.

Demikian pula sebaliknya, jika diserahkan sepenuhnya kepada preferensi spiritualitas masing-masing individu sedangkan organisasi tidak memiliki ikatan nilai-nilai spiritualitas yang dapat dijadikan sebagai pedoman maka beberapa potensi konflik akan terjadi. Kekacauan organisasi muncul akibat masing-masing individu bertahan pada preferensi spiritualitasnya. Tidak ada toleransi dan kesadaran antar individu. Hal ini juga akan mendorong perilaku yang disfungsional sehingga mengganggu kinerja organisasi dalam jangka panjang.

Penulis mencoba menggunakan perspektif yang berbeda dibandingkan dua pendekatan sebelumnya. Penulis menyebut pendekatan ini sebagai "religion's values perspective". Perspektif ini memandang bahwa dalam organisasi perlu mengakomodasi berbagai keyakinan spiritualitas individu yang berbeda-beda namun tetap diikat oleh aturan-aturan organisasi. Ada kebebasan spiritual yang diberikan oleh organisasi sepanjang tidak bertentangan dengan norma organisasi. Dengan kata lain, "ada kebebasan namun terikat". Memang tidak menutup kemungkinan akan terjadi gesekan, ketegangan atau konflik kepentingan antar individu, namun hal ini dapat diatasi dengan mengacu pada aturan-aturan organisasi yang telah ada. Dalam pandangan penulis, norma-norma organisasi semestinya dibangun dari nilai-nilai ke-Ilahiyan yang bersifat dogmatis dan tidak bisa diganggu gugat.

Oleh karena itu, penulis mencoba memberikan alternatif model untuk merevisi model yang dikembangkan oleh Krishnakumar \& Neck (2002). Dalam hal ini kedudukan agama (religion) harus berada di atas keyakinan spiritualitas organisasi maupun individunya. Nilai-nilai kebaikan yang melekat pada konsep spiritualitas seseorang sebenarnya berasal dari nilai-nilai agama yang sudah ada sebelumnya (Bruce, 1996). Baik orang itu beragama ataupun tidak. Baik ia menyadari ataupun tidak. Pengetahuan manusia tidak muncul secara tiba-tiba ataupun dengan sendirinya tanpa ada sesuatu yang menyebabkan hal itu terjadi. Pengetahuan manusia diperoleh dari Tuhan. Tuhan menurunkan ilmu-Nya melalui perantaraan Nabi dengan agama, wahyu dan kitabnya untuk disampaikan kepada manusia yang lain. Dalam perspektif Islam dijelaskan bagaimana proses tersebut terjadi. QS. Al Baqarah ayat 31 dan 33

31. Dan Dia mengajarkan kepada Adam nama-nama (benda-benda) seluruhnya, kemudian mengemukakannya kepada para Malaikat lalu berfirman: "Sebutkanlah kepada-Ku nama benda-benda itu jika kamu mamang benar orang-orang yang benar!"

Dan,

33. Allah berfirman: "Hai Adam, beritahukanlah kepada mereka nama-nama benda ini." Maka setelah diberitahukannya kepada mereka nama-nama benda 
itu, Allah berfirman: "Bukankah sudah Ku katakan kepadamu, bahwa sesungguhnya Aku mengetahui rahasia langit dan bumi dan mengetahui apa yang kamu lahirkan dan apa yang kamu sembunyikan?"

Selanjutnya mendasarkan pada justifikasi QS. Al Baqarah ayat 31 dan 33 maka gambar 2 berikut menunjukkan model yang dikembangkan penulis untuk merevisi model Spiritual Diversity-nya Krishnakumar \& Neck (2002).

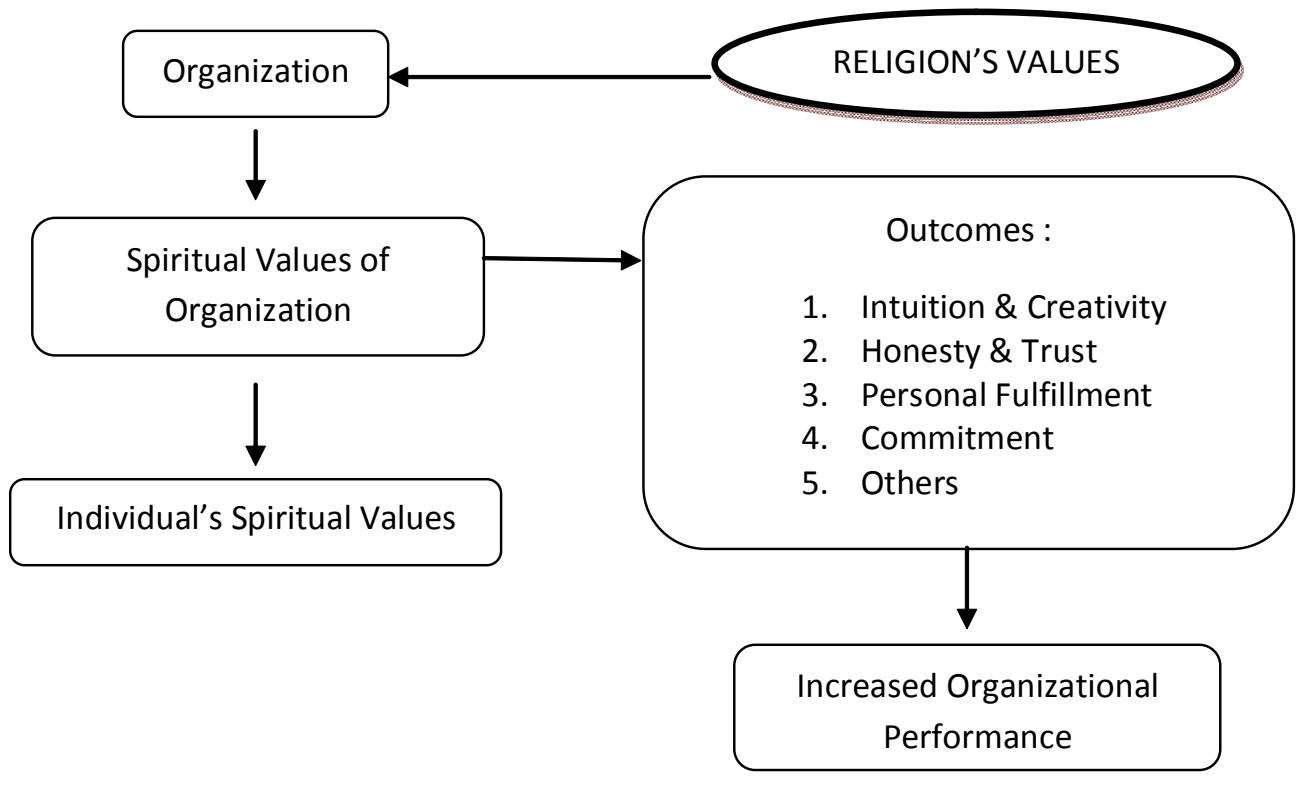

Gambar 2

Model Religion's Values (Model revisi oleh Penulis, 2011)

\section{Temuan Empiris Dalam Konteks Etika Kerja Islami}

Bagian ini penulis paparkan untuk memberikan gambaran bahwa nilai-nilai agama (religion's values) yang dalam hal ini mengambil sudut pandang Islam juga mengandung nilai-nilai spiritualitas yang berlaku umum baik bagi individu maupun organisasi. Sulistiyo (2004) melakukan penelitian yang mengambil sampel auditor internal yang bekerja di perusahaan manufaktur yang listing di Bursa Efek Jakarta. Penelitian ini menjelaskan bagaimana nilai-nilai yang terkandung dalam etika kerja Islami mempunyai pengaruh yang positif dan signifikan terhadap komitmen profesi dan komitmen organisasi seorang auditor internal serta sikapnya terhadap perubahan organisasi. Hasil kajian empiris Astri (2003) maupun Syafiq dan Achmad (2002) mendukung kesimpulan yang sama. Berikut lebih rinci hasil dari penelitian tersebut.

\section{Keterkaitan antara etika kerja Islami terhadap komitmen profesi}

Sulistiyo (2004) dan Astri (2003) menunjukkan bahwa nilai-nilai dalam etika kerja Islami berpengaruh positif dan signifikan terhadap terhadap komitmen profesi seorang akuntan. Nilai-nilai dalam etika kerja Islami mengandung tuntunan dan pedoman bagi setiap orang dalam menjalankan tugas atau pekerjaannya. Dalam terminologi Islam, bekerja memiliki dua dimensi yang penting yaitu dimensi duniawi dan dimensi ibadah. Bekerja bukan semata-mata sebagai upaya untuk memenuhi kebutuhan hidup secara layak namun lebih daripada itu bekerja merupakan kegiatan ibadah yang mendatangkan pahala dan kebaikan baik di dunia maupun akhirat kelak. Hal ini sejalan dengan dengan Syafiq dan Achmad (2002) yang menyatakan bahwa bekerja merupakan perbuatan yang sarat dengan nilainilai religius.

Etika kerja Islami menganjurkan setiap orang untuk bekerja dengan sungguhsungguh, jujur dalam menjalankan tugas dan memiliki komitmen yang tinggi terhadap profesi yang dijalaninya, tak terkecuali dalam hal ini adalah profesi auditor internal. Dalam kenyataannya, profesi auditor internal sebagai bagian dari perusahaan sering mengalami dilema dalam menjalankan tugasnya. Di satu sisi 


\section{Peran Spiritualitas Keagamaan...}

136

harus bertanggung jawab kepada perusahaan sedangkan di sisi yang lain tetap memegang teguh komitmen pada profesinya. Kondisi yang dilematis terjadi pada saat perusahaan atau pihak manajemen ingin memanipulasi angka-angka dalam laporan keuangan sedangkan auditor internal diberikan tugas untuk melakukan hal tersebut dan menutupi kebohongannya dari pandangan publik (Sulistiyo, 2004). Sebagai seorang auditor internal yang patuh pada aturan dank ode etik profesi tentunya harus tetap jujur dan menjalankan tugas dengan sebaik-baiknya.

Jika seorang auditor internal memahami dengan baik etika kerja dalam Islam yang bersifat universal dan mengandung nilai-nilai ibadah tentunya mereka tidak akan lagi mengalami kondisi yang dilematis. Mereka memiliki satu tujuan yang jelas ketika menjalankan tugas atau pekerjaannya yaitu bekerja dengan jujur, patuh pada kode etik profesi dan bersikap independen terhadap tekanan dari pihak manapun untuk berbuat kecurangan atau kejahatan. Hal ini secara implisit menyatakan bahwa yang seharusnya ditakuti dan ditaati oleh auditor internal bukan pihak manajemen atau pihak lain yang mengajak berbuat kecurangan melainkan Tuhan semata.

\section{Keterkaitan antara etika kerja Islami terhadap komitmen organisasi}

Sebagaimana telah dijelaskan sebelumnya, bahwa nilai-nilai etika kerja Islami bukan hanya mendorong seseorang untuk loyal kepada profesi yang dijalaninya namun juga meningkatkan komitmen terhadap organisasi yang dinaunginya tak terkecuali profesi auditor internal. Organisasi atau perusahaan memberikan wadah untuk mengembangkan karir, menyalurkan kreatifitas dan memperoleh pendapatan atau penghasilan untuk memenuhi kebutuhan hidupnya.

Organisasi atau perusahaan yang semakin berkembang dan maju tentunya akan menguntungkan bagi anggota organisasi atau karyawannya. Hal ini tidak dapat dilepaskan dari peran anggota dalam upaya memajukan organisasi. Karyawan yang aktif berpartisipasi pada akhirnya akan tumbuh rasa memiliki (sense of belonging) terhadap organisasinya. Adanya nilai-nilai dalam etika kerja Islami yang mendorong untuk bekerja dengan sungguh-sungguh demi kemajuan organisasi akan berdampak positif pada peningkatan komitmen organisasinya (Sulistiyo, 2004).

\section{Keterkaitan antara etika kerja Islami pada sikap terhadap perubahan organisasi}

Dalam setiap organisasi atau perusahaan, perubahan merupakan suatu hal yang wajar dan lazim terjadi. Perubahan yang terjadi dalam internal organisasi dilakukan untuk mengantisipasi dan menyesuaikan terhadap perkembangan lingkungan eksternal. Kondisi ini menuntut setiap anggota organisasi untuk bersikap terbuka dan mau menerima perubahan yang terjadi dalam lingkungan organisasinya. Fakta empiris menunjukkan bahwa mereka yang memegang nilai-nilai etika kerja Islami lebih dapat menerima segala perubahan dalam organisasinya (Sulistiyo, 2004; Astri, 2003).

\section{Rehabilitasi hati akuntan}

Mengamati berbagai kejadian yang mencoreng wajah akuntan seperti manipulasi laba, rekayasa laporan keuangan, kecurangan finansial, modifikasi laporan audit dan tindakan kriminal lainnya tentu akan meneteslah air mata kita. Begitu banyak cercaan yang datang menghampiri profesi akuntan sehingga muncullah kesangsian publik terhadap kinerja dan akuntabilitas akuntan. Laporan akuntan cenderung menutupi kondisi keuangan yang jelek dari perusahaan namun sebaliknya menampilkan hal-hal yang baik saja tentang perusahaan.

Menjadi pertanyaan besar adalah bagaimana cara yang paling efektif untuk menanamkan etika dan moralitas pada diri pribadi akuntan? apakah tidak pernah diajarkan di sekolah kita mulai dari tingkat dasar hingga perguruan tinggi pelajaran tentang kejujuran dan kebenaran dalam bertindak. Berapa jam dan SKS 
yang harus kita habiskan untuk melahap semua materi tersebut ? dan banyak pertanyaan lain yang sampai dengan saat ini kita belum memiliki jawaban yang pasti bagaimana solusi atas permasalahan tersebut.

Tidak bisa dipungkiri bahwa perbuatan dan tingkah laku yang baik, jujur dan benar dihasilkan dari proses yang terjadi dalam diri manusia. Perilaku yang nampak dari diri kita dihasilkan dari sesuatu yang ada dalam diri kita. Sesuatu itu adalah "hati" atau "qolbu" atau "heart". Hati menentukan apakah seseorang akan berbuat baik atau buruk. Kalau hati kita tidak dapat membedakan mana yang baik atau buruk berarti hati kita "bermasalah". Sebagaimana Rasulluloh SAW bersabda "Ketahuilah bahwasanya dalam tubuh ini ada segumpal daging. Jika baik segumpal daging itu, maka baik pula seluruh tubuhnya. Dan jika rusak segumpal daging segumpal daging tersebut, maka rusak pula seluruh tu-buhnya. Ketahuilah bahwa segumpal daging itu adalah hati”. (HR. Bukhari Muslim). Hadits ini merupakan penegasan bahwa perbaikan hati memiliki prioritas utama bagi seorang manusia (As Sewed, 2004). Oleh karena itu "tesis" penulis mengatakan bahwa untuk merehabilitasi citra dan nama baik profesi akuntan maka kita juga harus 'merehabilitasi" hati pribadi-pribadi akuntan.

Bahwa cara yang terbaik untuk 'merehabilitasi' hati kita adalah dengan meningkatkan kualitas keimanan dan keagamaan kita. Sebagaimana As Sewed (2004) menyatakan bahwa meningkatkan kualitas hati mustahil dilakukan tanpa memiliki akidah dan keimanan yang benar. Kalau ditanyakan apakah itu bisa dilakukan secara menyeluruh padahal urusan keyakinan dalam beragama merupakan kebebasan individu ? maka jawabannya adalah mulai dari diri kita dan jangan berpikir dulu untuk memperbaiki orang lain. Ketika setiap diri akuntan memperbaiki 'hatinya' maka lambat laun seluruh akuntan akan memiliki napas dan semangat yang sama sehingga hal yang mustahil tadi menjadi mungkin bukan?

\section{SIMPULAN}

Nilai-nilai spiritualitas yang kita yakini selama ini apapun bentuknya tidaklah muncul secara tiba-tiba dalam alam kesadaran manusia tanpa ada sesuatu yang menyebabkannya. Agama dihadirkan untuk memperbaiki perilaku manusia dan menjadi pegangan serta pedoman dalam menjalani hidup ini, termasuk tuntunan dalam kita bekerja. Oleh karena itu, agama merupakan pondasi yang menjadi dasar dalam mengembangkan nilai-nilai spiritualitas dalam jiwa manusia. Dalam konteks tersebut, penulis merevisi model Spiritual Diversity yang dikembangkan Krishnakumar dan Neck (2002) dengan menawarkan alternatif model yaitu model Religion's Values.

Model Religion's Values ini dibuktikan dengan hasil temuan empiris riset Sulistiyo (2004) dalam sudut pandang Islam yang menyimpulkan bahwa nilainilai etika kerja Islami seorang auditor internal mempunyai pengaruh positif dan signifikan terhadap komitmen profesi, komitmen organisasi dan sikap terhadap perubahan organisasi. Fakta ini menegaskan bahwa spiritualitas merupakan turunan dari keyakinan beragama karena pada dasarnya agama-agama yang ada, banyak mengajarkan nilai-nilai kebaikan sehingga ter-refleksikan ke dalam nilai-nilai spiritualitas.

\section{REFERENSI}

Aranya, N. dan K. R. Ferris. 1984. "Reexamination of Accountant Organizational Professional Conflict". Accounting Review. Vol 59 No. 1. hal 1-12.

As Sewed. M, Umar. 2004. "Dakwah Salaf adalah Dakwah Tauhid". As-Salafy, Kategori Manhaj Diunduh tanggal 29 Desember 2010. <http:// www.salafy.or.id>.

Astri, F. 2003. "Pengaruh Etika Kerja Islam terhadap Sikap Akuntan dalam Perubahan Organisasi dengan Komitmen Organisasi sebagai Variabel Inter- 


\section{Peran Spiritualitas Keagamaan...}

138 vening”. Tesis S2 Program Pasca Sarjana. Universitas Diponegoro (tidak dipublikasikan).

Bruce, S. 1996. Religion in the modern world. Oxford University Press. Oxford.

Burack, E.H. 1999. "Spirituality in the workplace". Journal of Organizational Change Management. Vo. 12. No. 4. hal 280-91.

Delbecq, L.A. 1999. "Christian spirituality and contemporary business leadership". Journal of Organizational Change Management. Vol. 12 No. 4. hal 345-9.

Francis, Jere R. 1990 "After virtue? accounting as a moral and discursive practice". Accounting, Auditing and Accountability Journal.

Freshman, B. 1999. "An exploratory analysis of definitions and applications of spirituality in the workplace". Journal of Organizational Change Management. Vol 12. No. 4. pp. 318-27.

Graber, D.R. 2001. "Spirituality and healthcare organizations". Journal of Healthcare Management. Vol. 46 No.1. hal 39-50.

Guillory, W.A. 2000. The living organization: spirituality in the workplace. Innovations International Inc. Salt Lake City. UT.

Hines, D. Ruth. 1992. "Accounting Filling The Negative Space”. Accounting, Organization, and Society.

Kahnweiler, W. and F.L. Otte. 1997. "In search of the soul of HRD". Human Resource Development Quarterly. Vol. 8 No. 2. hal 171-81.

Kriger, M.P. dan B.J. Hanson. 1999. "A value based paradigm for creating truly healthy organizations". Journal of Organizational Change Management. Vol. 12 No. 4. hal 302-17.

Krishnakumar, S. and C. P. Neck. 2002. "The "what", "why", and "how" of spirituality in the workplace". Journal of Managerial Psychology. Vol. 17 No. 3. hal 153-164.

Leigh, P. 1997. "The new spirit at work". Training and Development. Vol 51 No. 3. hal 26-34.

Maynard, H.B. 1992. “The evolution of human consciousness. In Renesch". J, (Ed.). New Traditions in Business. Berrett-Koehler. San Francisco. CA. hal 39-52.

Meyer, J. P. and N. J. Allen. 1984. "Testing the side-bet of Organizational Commitment: Some Methodological Considerations". Journal of Applied Psychology. 69 (August). hal 372-378.

"Commitment to Organizations and Occupation: Extensions and Test of ThreeComponent Conceptualization”. Journal of Applied Psychology. Vol. 78. No. 4. hal 538-551.

Mitroff, I.I. and EA Denton. 1999. A spiritual audit of corporate America. JosseyBass Publishers. San Francisco. CA.

Morgan, Gareth. 1988. "Accounting as reality construction: towards a new epistemologi for accounting practice". Accounting, Organizations, and Society.

Mowday, R.T. RM. Steers. dan LW. Porter. 1979. "The Measurement of Organizational Commitment". Journal of Vocational Behavior. Vol 14 (2). hal 224-47.

Muhammad. 2008. Paradigma, Metodologi dan Aplikasi Ekonomi Syari'ah. Penerbit Graha Ilmu. Yogyakarta.

Nasron A. 2002. "Pengaruh Etika Kerja Akuntan terhadap Komitmen Profesi dan Komitmen Organisasi”. Tesis S2 Program Pasca Sarjana Universitas Diponegoro (tidak dipublikasikan).

Naylor, T.H. Willimon, W.H. and R. Ossterberg. 1996. The search for meaning in the workplace. Abington Press. Nashville. TN.

Neck, C.P. and JF. Milliman. 1994. "Thought self-leadership:finding spiritual fulfillment in organizational life". Journal of Managerial Psychology. Vol. 9 No. 6. hal 9-16. 
Ray, M.L. 1992. "The emerging new paradigm in business, in Renesch, J. (Ed)".

New Traditions in Business. Berrett-Koehler. San Francisco. CA, hal 25-38.
ins, S. 2001. Perilaku Organisasi. Terjemahan Jilid 1. Prenhallindo. Jakarta.

Roslender, R. 1992. Sociological perspectives on modern accountancy. Routledge. New Fetterlane. London.

Sukoharsono, E. G. 2008. "Religion, spirituality, and philosophy:how do they work for an accounting world?". The third Postgraduate Consortium in Accounting: Socio Spiritual Accounting, The Department of Accounting. The University of Brawijaya.

Sulistiyo, A. B. 2004. "Komitmen profesi dan komitmen organisasi sebagai variabel intervening dalam hubungan antara etika kerja Islami dan sikap terhadap perubahan organisasi”. Tesis Magister. Undip. Semarang.

Syafiq M. H. dan A. Sobirin. 2002. "Relevansi Ajaran Agama Dalam Aktifitas Ekonomi (Studi Komparatif Antara Ajaran Islam dan Kapitalisme)”. Prosiding Simposium Nasional I Sistem Ekonomi Islam.

Triyuwono, I. 2006. Perspektif, Metodologi. Dan Teori Akuntansi Syariah. Edisi Satu. Jakarta: PT RajaGrafindo Persada.

Turner, J. 1999. "Spirituality in the workplace". caMagazine. Vol. 132 No. 10. hal 41-2.

Wagner-Marsh, F. and J. Conely. 1999. "The fourth wave: The spirituality based firm". Journal of Organizational Change Management. Vol. 12 No. 4. hal 292301.

Yousef, D. A. 2000. "Organizational Commitment as a Mediator of The Relationship between Islamic Work Ethics and Attitudes toward Organizational Change". Human Relations. Vol. 53 (4). hal 513-537. 
